Lizabeth Bowen $^{\mathrm{a}}$, A. Keith Miles ${ }^{\mathrm{a}}$, Jeffrey Stott $^{\mathrm{b}}$, Shannon Waters ${ }^{\mathrm{a}}$, Todd Atwood ${ }^{\mathrm{c}}$ 5

\title{
Enhanced biological processes associated with alopecia in polar bears (Ursus maritimus)
}

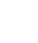

${ }^{a}$ U.S. Geological Survey, Western Ecological Research Center, Davis, CA, 95826, USA

${ }^{\mathrm{b}}$ Department of Pathology, Microbiology, and Immunology, School of Veterinary Medicine, University of California, Davis, CA, 95616, USA

${ }^{c}$ U.S. Geological Survey, Alaska Science Center, Anchorage, AK, 99508, USA

Corresponding author:

Lizabeth Bowen

Email: $\underline{\text { bowen@usgs.gov }}$

Phone: 530-752-5365

\section{Abstract}

Populations of wildlife species worldwide experience incidents of mass morbidity and mortality. Primary or secondary drivers of these events may escape classical detection methods for identifying microbial insults, toxin exposure, or additional stressors. In 2012, 28\% of polar bears sampled in a study in the southern Beaufort Sea region of Alaska had varying degrees of alopecia that was concomitant with reduced body condition. Concurrently, elevated numbers of sick or dead ringed seals were detected in the southern Beaufort, Chukchi, and Bering seas in 2012, resulting in the declaration of an unusual mortality event (UME) by the National Oceanic and Atmospheric Administration (NOAA). The primary and possible ancillary causative stressors of these events are unknown, and related physiological changes within individual animals have been undetectable using classical diagnostic methods. Here we present an emerging technology as a potentially guiding investigative approach aimed at elucidating the 
27 circumstances responsible for the susceptibility of certain polar bears to observed conditions.

28 Using transcriptomic analysis we identified enhanced biological processes including immune

29 response, viral defense, and response to stress in polar bears with alopecia. Our results support

30 an alternative mechanism of investigation into the causative agents that, when used proactively,

31 could serve as an early indicator for populations and species at risk. We suggest that current or

32 classical methods for investigation into events of unusual morbidity and mortality can be costly,

33 sometimes unfocused, and often inconclusive. Advances in technology allow for

34 implementation of a holistic system of surveillance and investigation that could provide early

35 warning of health concerns in wildlife species important to humans.

36

37

38

39

40

41

42

43

44

45

46 Key words: polar bear, transcriptome, Unusual Mortality Event, ecosystem health 


\section{Introduction}

Polar bears (Ursus maritimus) are a flagship, sentinel species of the Arctic with a

50 distribution limited to regions where sea ice provides adequate access to marine mammal prey,

51 and a substrate for maternity dens and efficient locomotion. However, the spatial extent of Arctic

52 sea ice during the autumn ice minimum period has declined by over $12 \%$ per decade based on

53 analysis of satellite imagery since 1979 (Stroeve et al. 2012), with higher rates of decline greatest

54 in marginal seas like the southern Beaufort (Stroeve et al. 2014). These dramatic changes to the

55 sea ice ecosystem have been implicated in reduced body condition, growth, survival, and

56 abundance of polar bears in the southern Beaufort Sea and elsewhere due, in part, to difficulty in

57 accessing prey (Regehr et al. 2007; Regehr et al. 2010; Rode et al. 2010). Consequently, the

58 long-term persistence of polar bears is threatened by rising global temperatures and the resulting

59 cascading effects, which have been projected to induce regional declines in abundance by $\sim 2050$

60 (Amstrup et al. 2008) unless greenhouse gas emissions are mitigated (Amstrup et al. 2010).

61 Indirect effects of climate change pose added risk to polar bears. Increased body burdens

62 of legacy contaminants in polar bears have been linked to climate change via altered trophic

63 interactions. In the western Hudson Bay region of the Canadian Arctic, changes in polar bear

64 foraging ecology have led to an increase in the proportions of open-water seal species (e.g., harp

65 [Phoca groenlandica] and harbor [Phoca vitulina] seals) represented in diets, along with a

66 concomitant increase in the tissue concentrations of several chlorinated and brominated

67 contaminants (McKinney et al. 2009). Similar changes have occurred in East Greenland where

68 harp seals and hooded seals (Cystophora cristata) have become more common and ringed seals

69 (Pusa hispida) more scarce as polar bear prey (McKinney et al. 2013). Studies also have found

70 associations between high levels of legacy chlorinated contaminants in certain polar bear 
71 subpopulations and biomarkers of toxic effects on endocrine, immune, and reproductive function

72 (Bernhoft et al. 2000; Polischuk et al. 2002; Lie et al. 2004; Lie et al. 2005; Letcher et al. 2010;

73 Sonne 2010; Bechshøft et al. 2012; Dietz et al. 2015; Jenssen et al. 2015).

74 In 2012, southern Beaufort Sea polar bears were observed with varying degrees of

75 alopecia, a syndrome characterized by patchy hair thinning and loss and occasional epidermal

76 lesions, often distributed irregularly over the body and associated with viral, bacterial, fungal,

77 and parasitic agents (e.g., Lynch et al. 2011) (Fig. 1). In fact, 28\% of polar bears captured in the

78 southern Beaufort Sea in 2012 were observed with varying degrees of alopecia (Atwood et al.

79 2015), as well as reduced body condition for adult females captured during this period (Bowen et

80 al. in press). The occurrence of alopecia in polar bears was preceded by the occurrence of a

81 similar condition in ringed seals, which resulted in the declaration of an unusual mortality event

82 by the National Oceanic and Atmospheric Administration [NOAA] (2011);

83 http://alaskafisheries.noaa.gov/protectedresources/seals/ice/diseased/factsheet112211.pdf. 


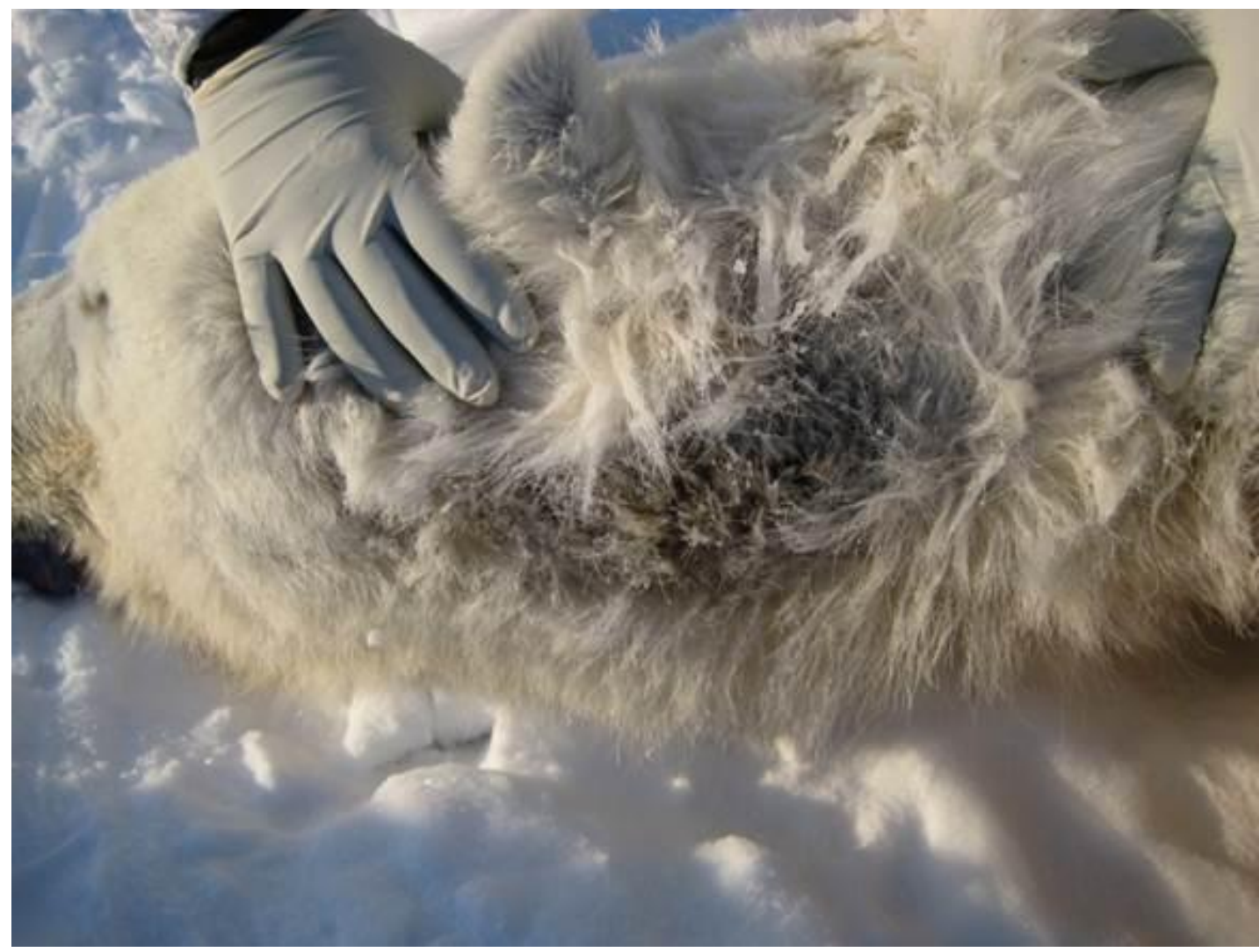

86

87 Fig. 1. Example of alopecia (e.g., thinning of hair on underside of neck) in southern Beaufort Sea 88 adult male polar bear (Ursus maritimus) captured on March 28, 2012 in Alaska, USA.

90 Evaluation of the health status of polar bears is based on a combination of the animal's history

91 (e.g., movement, reproductive status), physical examination, and clinical pathology data.

92 Health diagnostics of polar bears have historically relied on the evaluation of select serum

93 biomarkers and the identification of contaminant or pathogen burden within specific tissues as

94 an indicator of a level of insult. However, the application of traditional diagnostic approaches

95 to identify the environmental and/or pathogen-related etiologies for alopecia in polar bears

96 proved unsuccessful (Atwood et al. 2015), highlighting the need for an alternative approach for 
97 assessing health, one that measures the influence of external factors on the welfare of the

98 individual, provides evidence of physiological reaction, and extends the scope of interpretation. holistic assessment of health not only in individuals or populations but potentially in ecosystems (Acevedo-Whitehouse and Duffus 2009). Until recently, study of only a small numbers of genes has been feasible, based on a priori selection of a candidate suite of genes (Bowen et al. 2007; Bowen et al. 2012; Miles et al. 2012; Bowen et al. 2015). However, recent advances in gene sequencing technology allow for the elucidation of an unprecedented breadth of gene pathways. Gene transcription is the process by which information from the DNA template of a particular gene is transcribed into messenger RNA (mRNA) and eventually translated into a function protein. The amount of a particular gene that is transcribed is physiologically dictated by a number of intrinsic and extrinsic factors, including stimuli such as infectious agents, toxin exposure, trauma, or neoplasia. The earliest observable signs of health impairment are altered levels of gene transcripts that are evident prior to clinical manifestation (McLoughlin et al. 2006). Broad scale identification of gene transcription patterns can provide mechanistic proxies of health (Pedersen and Babayan 2011). Identifying causal links between exposure to stressors, gene transcript patterns, and individual and population health become possible.

Herein we describe the use of deep sequencing technology to investigate the etiology of a high incidence of alopecia in polar bears. Deep sequencing indicates that the total number of reads is many times larger than the length of the sequence under study, in effect increasing the accuracy of the read. Identification of genes and gene pathways associated with altered physiologic manifestations could provide insight into the causes of specific disease states as 
119 well as provide the basis for development of a system for early identification of compromised

120 health and related environmental stressors in free-ranging animals and ecosystems.

\section{2. Materials and methods}

122 2.1. Polar bears

123

Blood samples from nineteen free-ranging polar bears in the southern Beaufort Sea of

Alaska were obtained during April, 2012. Nine polar bears were identified with alopecia syndrome ( 3 adults, 5 subadults, 1 2-yr old cub; 4 males, 5 females). Ten polar bears were identified as clinically normal (10 adults; 6 females, 4 males). Polar bears were immobilized from a helicopter using Telazol ${ }^{\circledR}$ (tiletamine hydrochloride a zolazepam hydrochloride; Zoetis, Florham Park, NJ) -filled projectile syringes fired from a dart gun. Captured bears were eartagged and tattooed with a unique identification number, body weight was determined using a spring or dynamometer scale, and body condition was determined by palpation following methods described in Stirling et al. (2008). Age was established using various methods including visual aging (cubs-of-the-year; Ramsay and Stirling 1988), capture history, and via analysis of cementum annuli from an extracted vestigial premolar (Calvert and Ramsay 1998).

\subsection{Blood collection and RNA extraction}

A $2.5 \mathrm{ml}$ sample from each polar bear was drawn directly into a PAXgene ${ }^{\mathrm{TM}}$ blood RNA collection tube (PreAnalytiX, Switzerland) from either the jugular or popliteal veins and then frozen at $-20^{\circ} \mathrm{C}$ until extraction of RNA. Rapid RNA degradation and induced transcription of certain genes after blood draws has led to the development of methodologies for preserving the RNA transcription profile immediately after blood is drawn. The PAXgene ${ }^{\mathrm{TM}}$ tube contains a blend of RNA stabilizing reagents that protect RNA molecules from degradation by RNases and prevent induction of gene transcription. Without this stabilization, copy numbers of individual 
142 mRNA species in whole blood can change dramatically during storage and transport. The RNA

143 from blood in PAXgene ${ }^{\mathrm{TM}}$ tubes was isolated according to manufacturer's standard protocols,

144 which included an on-column DNase treatment to remove contaminating gDNA (silica-based

145 microspin technology), and the extracted RNA stored at $-80^{\circ} \mathrm{C}$ until analysis.

\section{2.3. Transcriptome analysis}

Tissue samples were used for individually barcoded directional RNASeq library preparations. The barcoded libraries were pooled and run on four lanes of Illumina HiSeq2500 to generate an estimated 30 million paired end reads (length 100x100) per sample. Read quality control was performed using tools developed in house by the University of California Davis Genome Center's Bioinformatics Core: the Bioconductor package Qrqc was used to calculate basic read quality metrics, Scythe and Sickle were used for Illumina adapter trimming and base quality trimming (https://github.com/ucdavis-bioinformatics). The trimmed reads were aligned to an existing polar bear draft genome and two related genomes (giant panda [Ailuropoda melanoleuca] and domestic ferret [Mustela putorius furo]) using Tophat2 (http://tophat.cbcb.umd.edu/; Kim et al. 2013). The alignment rate to the polar bear draft genome was the highest (> 65\%) compared to alignment to either of the other two genomes $(<60 \%)$. Therefore, giant panda and domestic ferret genomes were not used for any further analysis. Although the alignment rate to the polar bear draft genome was higher than to other genomes, the alignment rate varied significantly among samples from $\sim 65 \%$ to $\sim 95 \%$. The completeness of the draft genome was then checked using the Core Eukaryotic Genes Mapping Approach (CEGMA) (Parra et al. 2007). Out of 248 core genes, only 212 are present in the draft genome. Furthermore, an assessment using BLAST (Basic Local Alignment Search Tool) of 12 genes that were studied by PCR against the draft genome resulted in partial hits for 5 genes and 
no hit for one gene. In order to obtain a reasonable quality of transcriptome, extra sequencing was performed on a larger quantity of template material (i.e., pooled tissue samples) and run on one HiSeq2500 lane, and these reads were pooled with all other RNA-Seq data in this study. In order to improve assembly quality, all reads were trimmed more aggressively - i.e. by setting Sickle's Q-value threshold to eliminate 3'-tails with average Q-value below 30, and by discarding trimmed reads shorter than 50bp long. All trimmed reads were first aligned to a custom carnivora ribosomal RNA (rRNA) database obtained from National Center for Biotechnology Information (Bethesda, MD) to remove any potential rRNA contamination. The assembly was carried out using Trinity (Grabherr et al. 2011)In silico normalization to a maximum coverage of 30x was done, based on recommendations at the time of this study by Trinity authors. Trinity was then used to assemble normalized reads, using default parameters. Functional annotation of the gene models was accomplished by an exhaustive annotation process using Blast2GO (http://www.blast2go.com; Conesa, et al. 2005; Götz et al. 2008).

Reads from individual tissue samples were aligned to the assembled transcriptome using BWA-mem with default parameters (http://bio-bwa.sourceforge.net/; Li and Durbin 2010); BWA is a software package for mapping low-divergence, unspliced sequences. Alignment rates for all samples were $>90 \%$. A custom Python script (sam2counts; https://github.com/ucdavisbioinformatics) was used to generate a table of raw transcript counts for each sample, which was then summed to obtain counts at the gene level. Subsequently, normalization of data and testing for differential transcription were done using edgeR, an R-based package for empirical analysis of digital gene transcription data (http://www.bioconductor.org/packages/release/bioc/html/edgeR.html; Robinson et al. 2010). Genes with false discovery rate values lower than 0.05 (which predicts $5 \%$ false positives in the 
188 set satisfying that cutoff) were considered to be significantly differentially expressed. Diagnostic

189 plots were produced to determine if transcription among each sample group, based on Euclidean

190 distance, was distinct from that of other groups. Gene Ontology (GO) enrichment in the list of

191 differentially expressed genes were generated using a hypergeometric test implemented in

192 GOstats (Falcon and Gentleman 2007). P-value output by the Hypergeometric tests were

193 adjusted for multiple comparisons using the method of Benjamini and Hochberg (1995). GO

194 terms that had adjusted P-values $<0.05$ were considered to be significantly enriched. GO terms

195 were further analyzed using ReVIGO, a web server that summarizes long lists of GO terms by

196 finding a representative subset of the terms. A simple clustering algorithm that relies on

197 semantic similarity measures was used to summarize GO terms. ReVIGO then visualizes the

198 non-redundant GO term set to assist in interpretation (Supek et al. 2011).

We used hierarchical cluster analysis and subsequent heat map generation to refine and

200 identify those genes most highly transcribed based on variance transformed data.

$201 \quad 3.0$ Results and Discussion

Approximately 9,000 genes were identified that were differentially transcribed between 203 alopecia symptomatic and asymptomatic polar bears. Using hierarchical cluster analysis and heat 204 map generation, we identified the 500 most highly transcribed genes (in all polar bears) that 205 could be categorized to definitive biological processes (Fig. 2). 

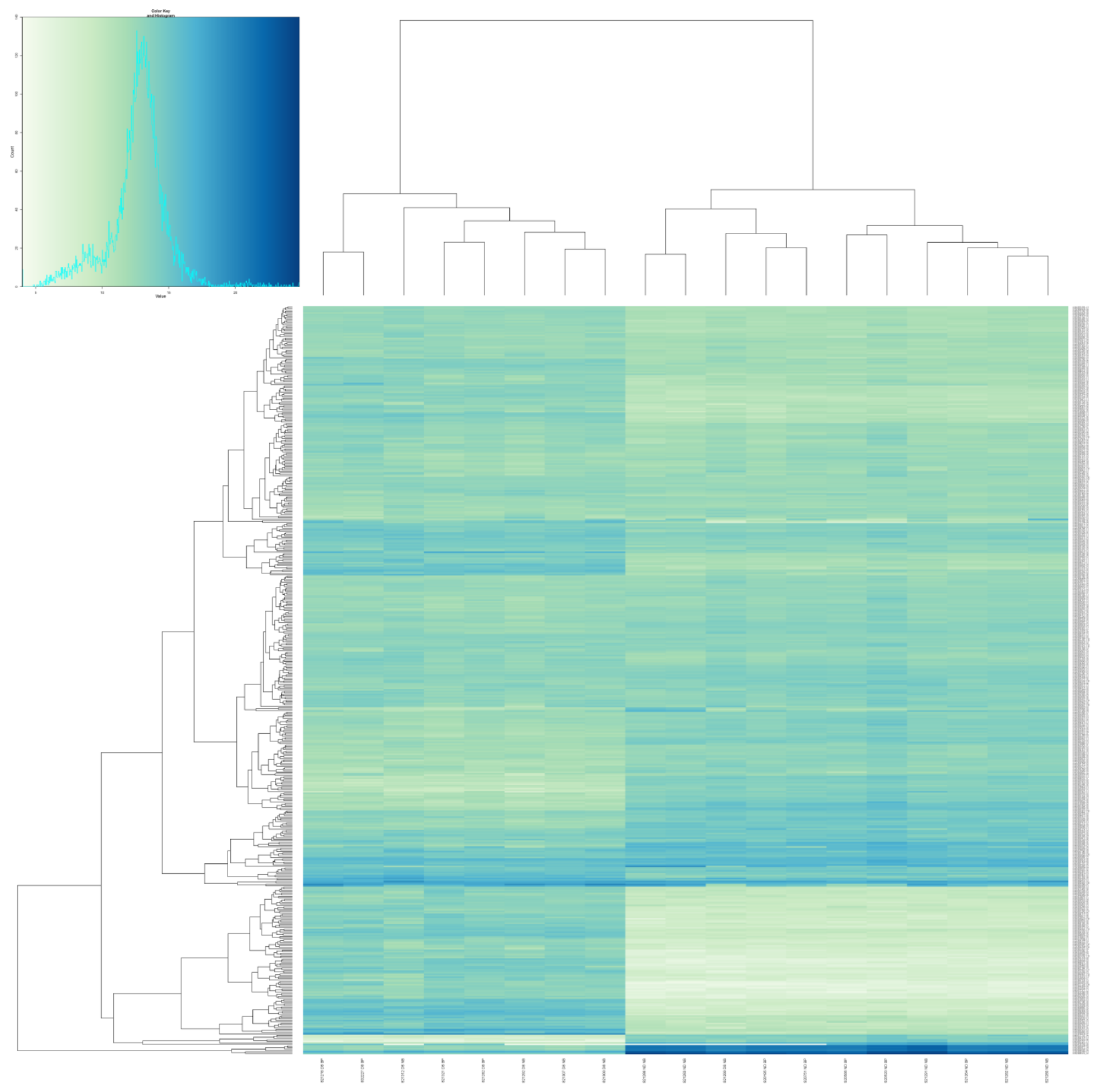

208 Fig. 2. Heat map showing the 500 most highly transcribed genes based on variance stabilization 209 transformed data. Each row corresponds to an individual gene. Each column represents one of 210 the 19 polar bears investigated in this study. Transcription signal intensity is denoted by color. 211 The tree structures to the left and on the top demonstrate similarities between genes and samples 
2

3

212 (i.e., the smaller the distance between tree branches, the greater the similarity), respectively,

213 according to the hierarchical cluster analysis results.

215 These analyses showed a remarkable demarcation between affected and unaffected individuals.

216 As validation of this technique for differentiating between symptomatic and asymptomatic

217 animals, one potentially affected polar bear was mistakenly clustered with the control animals in

218 the first analysis. Due to the outlying nature of results, reexamination of the data on this animal

219 revealed that it had been miscategorized. What we thought was hair loss attributed to alopecia

220 was actually recorded as hair imbedded in ice in and around the ear that was removed by

221 scratching activity of the bear.

222 A large number (405) of biological processes were significantly enriched in affected 223 polar bears relative to unaffected animals (Fig. 3). 


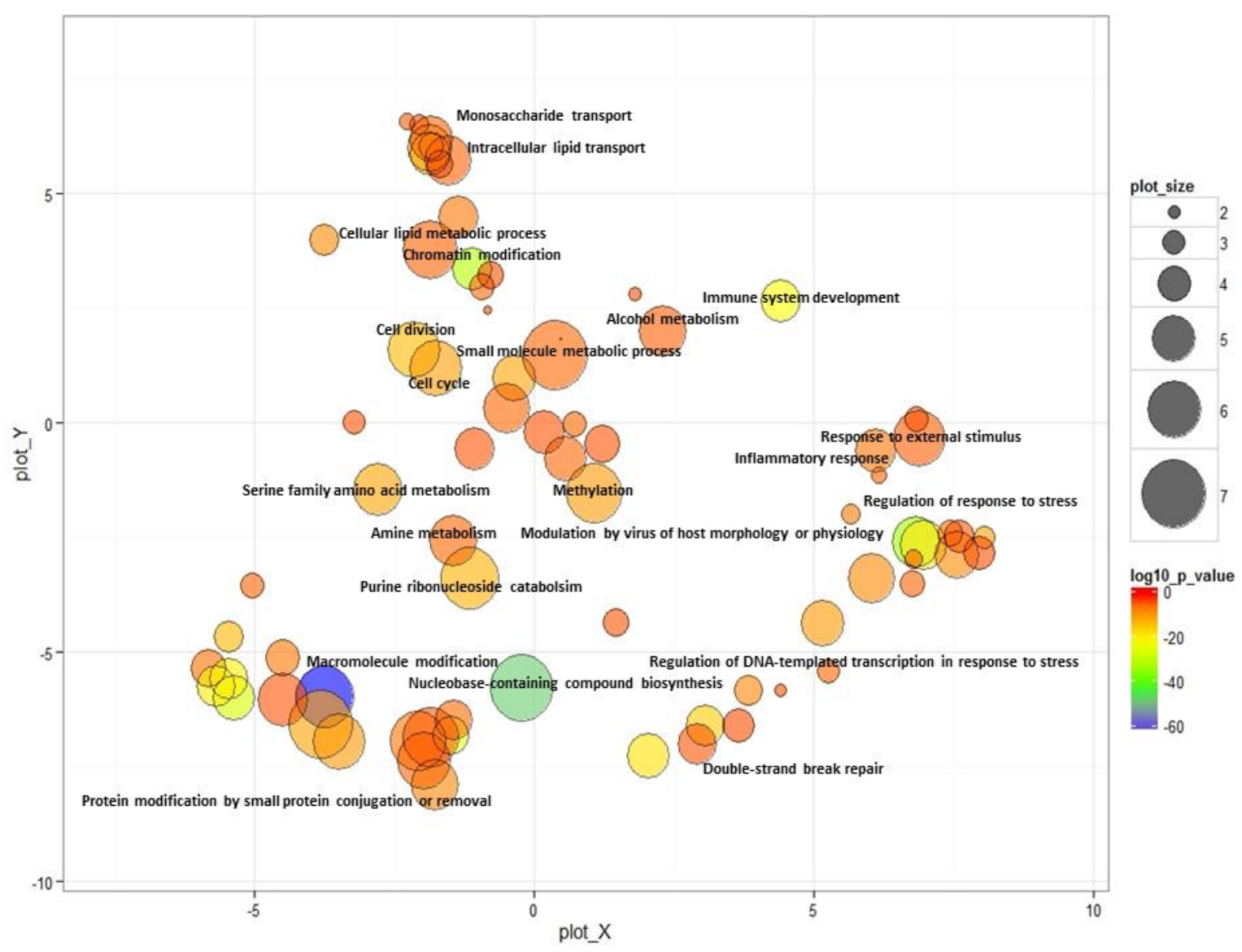

225 Fig. 3. Biological processes enriched in polar bears exhibiting signs of alopecia. ReVIGO

226 scatterplot of GO categories enriched in alopecic polar bears (GO over-representation analysis

227 (ORA), Benjamini-Hochberg corrected $\mathrm{P}<0.05)$, with blue circles denoting higher enrichment,

228 circle size denoting the frequency of the GO term in the underlying database (bubbles of more general

229 terms are larger) and semantically similar (simRel) GO terms closer to each other. Labels indicate 230 processes particularly relevant to interpretation.

232 An enrichment of a multitude of processes associated with intracellular pathogens was evident in 233 affected polar bears, including genes involved in major histocompatibility complex (MHC) class 234 I-associated antigen processing and presentation, toll-like receptors 7 and $8, N F \kappa \beta$ and 
2

235 interferons $\alpha$ and $\gamma$. Processes associated with inflammation and immune system activation were enriched in affected polar bears including T lymphocyte activation functions, as well as

237 transcription activity of response regulation to stress genes. DNA damage response-associated

238 gene transcripts were altered in affected polar bears and included enrichment of methylation

239 processes, histone trimethylation, double strand DNA repair, and p53 mediated DNA damage

240 response. In addition, enrichment of aromatic compound catabolic processes and altered fatty

241 acid biosynthesis regulation was identified in polar bears exhibiting signs of alopecia and

242 decreased body condition.

243 These results led us to the formation of system-specific conceptual drivers of ecology and 244 immunology (Fig. 4). 
246 Fig. 4. Conceptual model of the potential climate change-driven factors affecting immune 247 function. Areas of overlap indicate probable causative links. Numbers indicate references: 1)

248 Durner et al. 2009, 2) Edwards et al. 2011, 3) Molnar et al. 2011, 4) Stirling and Derocher 2012 ,

249 5) Derocher et al. 2013, 6) Cherry et al. 2009, 7) Polischuk et al. 2002, 8) Christensen et al.

250 2007, 9) Helgason et al. 2013, 10) Thiemann et al. 2008, 11) McKinney et al. 2009, 12) 
McKinney et al. 2013, 13) Macdonald et al. 2005, 14) Carrie et al. 2010, 15) Vos et al. 2000, 16) Acevedo-Whitehouse and Duffus 2009, 17) Saucillo et al. 2014.

A proportion of the polar bear population in the southern Beaufort region of Alaska has switched 255 from a diet comprised primarily of ringed seals to a more flexible foraging strategy that includes 256 shore-based scavenging during summer and fall on marine mammal carcasses resulting from 257 human hunters (Rogers et al. 2015). Increased exposure frequency to certain prey items, and 258 associated behaviors such as foraging on shore (Schliebe et al. 2008), may expose the polar bears 259 to pathogens not previously encountered, possibly challenging typical immune response. 260 Alternate marine-based prey items may carry increased contaminant burdens (Macdonald et al. 261 2005; Thiemann et al. 2008; McKinney et al. 2009, 2013; Carrie et al. 2010) further impacting 262 immunologic response(s) (Vos et al. 2000). While foraging on terrestrial-based prey and 263 vegetation would likely reduce contaminant burdens (Ramsay and Hobson 1991; Gormezano and 264 Rockwell 2013a,b; Iles et al. 2013), it is unlikely to offset nutritional deficiency resulting from 265 lost foraging opportunities on lipid-rich marine mammal prey (Rode et al. 2015). Perhaps 266 simultaneously, increased resource allocation to facilitate extended swimming or foraging bouts 267 due to diminishing sea ice could affect immune function or efficiency (Saucillo et al. 2014). 268 Moreover, nutritional deficiency could mobilize contaminants stored in blubber, further taxing 269 immune function (Letcher et al. 2010) and facilitating disease susceptibility. 270 Continued transcription of genes responsible for immunologic function, including 271 detoxification, can be physiologically costly (Graham et al. 2010). Perhaps the largest cost is the 272 reallocation of nutrients and energy from one portion of an individual's resource budget 
273 to other metabolic functions. Mitigation of stressors imposes demands on animals above those

274 normally required to sustain life and may result in reduction of fitness evidenced by decreased

275 reproductive capability, increased susceptibility to disease, or disadvantageous behavioral

276 changes (Graham et al. 2010; Martin et al. 2010).

\section{3.1. Conclusions} unusual morbidity and/or mortality events: 1) investigations using standard and widely accepted diagnostics may not be sufficiently sensitive to provide clues as to the causative agents, and 2) although advanced technologies provide far better resolution of potential ecological and immunological drivers, the post-event timing of the investigation may prohibit clear insight into the ecological pathways involved. At the time of death, or disease state, an organism is clearly at the latter stages of a succession of physiological, biochemical, and immunological events triggered by one or more causative incidents. The number of enriched pathways identified in polar bears with alopecia syndrome is a prime example of this: by the time clinical manifestation has occurred, ample time has elapsed in a physiological system already operating sub-optimally for additional conditions to manifest. Even with the dramatic advances in technology experienced over the past decade, the current paradigm of investigations 'after the fact' will not suffice to properly understand causative effects. Historically, large scale investigations into populations and ecosystems have been driven by catastrophic events (i.e., unusual mortality events). These have relied heavily on information obtained using routine clinical diagnostics and pathology from sick or deceased animals. We suggest a different approach, i.e. using a model of baseline and long-term monitoring of sensitive molecular parameters (e.g., gene transcription patterns) to continually assess populations for subtle yet significant changes. We can use the 
current approach to refine the direction of further research efforts; in this case, we could, with some degree of confidence, point at microbial, nutritional, and toxin exposure as components contributing to the alopecia syndrome. In the future, we may gain considerably in our ability to understand why species are at risk if we take a proactive approach of monitoring populations prior to the onset of clinical manifestation. Such a proactive approach would negate in part the

\section{Acknowledgements}

We are grateful for the technical expertise of Isabelle Henry, Henriette O'Geen, and the UC Davis Genome Center Core Facilities, specifically Jie Li, Monica Britton, Joe Fass, and Blythe Durbin-Johnson. Transcriptome assembly, differential expression, and gene enrichment analyses were carried out by Jie Li. We thank G. Durner, K. Simac, E. Peacock, A. Pagano, K. Rode, and T. Donnelly for their assistance with polar bear captures and sampling. We thank the US Fish and Wildlife Service Polar Bear Program, including E. Regehr, M. St. Martin, and R.

Wilson, for sampling polar bears in the Chukchi Sea which was critical to foundational work on this topic and for establishing baseline data for future monitoring efforts. This work was funded through the U.S. Geological Survey, Ecosystems Mission Area and the Changing Arctic Ecosystems Initiative. Any use of trade, product or firm names in this publication is for descriptive purposes and does not imply endorsement by the U.S. government.

\section{References}


Acevedo-Whitehouse K, Duffus LJ. Effects of environmental change on wildlife health. Philos Trans R Soc B 2009;364:3429-3438.

Amstrup SC, Marcot BG, Douglas DC. A Bayesian network modeling approach to forecasting the 21 st century worldwide status of polar bears. In: DeWeaver ET, Bitz CM, Tremblay LB, editors. Arctic sea ice decline: Observations, projections, mechanisms, and Implications. Washington DC, American Geophysical Union; 2008. p. 213-268.

Amstrup SC, DeWeaver ET, Douglas DC, Marcot BG, Durner GM, Bitz CM, Bailey DA.

Greenhouse gas mitigation can reduce sea-ice loss and increase polar bear persistence. Nature 2010;468:955-958.

Atwood TC, Peacock E, Burek-Huntington K, Shearn-Bochsler V, Bodenstein, B, Beckmen K, Durner GM. Prevalence and spatio-temporal variation of an alopecia syndrome in polar bears of the southern Beaufort Sea. J Wildl Dis 2015;51:48-59.

Bechshøft Tø, Sonne C, Dietz R, Born EW, Muir DCG, Letcher RJ, Novak MA, Henchey E,

Meyer JS, Jenssen BM, Villanger GD. Associations between complex OHC mixtures and thyroid and cortisol hormone levels in East Greenland polar bears. Environ Res 2012;116:26-35.

Benjamini Y, Hochberg Y. Controlling the false discovery rate: a practical and powerful approach to multiple testing. J R Stat Soc, Ser B 1995;57:289-300.

337 Bernhoft A, Skaare JU, Wiig O, Derocher AE, Larsen HJS. Possible immunotoxic effects of 338 organochlorines in polar bears (Ursus maritimus) at Svalbard. JToxicol Environ Health $339 \quad 2000 ; 59(\mathrm{Pt} \mathrm{A}): 561-574$. 
Bowen L, Riva F, Mohr C, Aldridge B, Schwartz J, Miles AK, Stott JL. Differential gene expression induced by exposure of captive mink to fuel oil: A model for the sea otter. EcoHealth 2007;4:298-309.

Bowen L, Miles AK, Murray M, Haulena M, Tuttle J, Bonn WV, Adams L, Bodkin JL, Ballachey B, Estes J, Tinker MT, Keister R, Stott JL. Gene transcription in sea otters (Enhydra lutris); emerging diagnostics in marine mammal and ecosystem health. Mol Ecol Res 2012;12:67-74.

Bowen L, Miles AK, Kolden CA, Saarinen JA, Bodkin JL, Murray MJ, Tinker MT. Effects of wildfire on sea otter (Enhydra lutris) gene transcript profiles. Mar Mamm Sci 2015;31:191-210.

Calvert W, Ramsay MA. Evaluation of age determination of polar bears by counts of cementum growth layer groups. Ursus 1998;10:449-453.

Carrie J, Wang F, Sanei H, Macdonald RW, Outridge PM, Stern GA. Increasing contaminant burdens in an arctic fish, burbot (Lotalota), in a warming climate. Environ Sci Technol 2010;44:316-322.

Cherry SG, Derocher AE, Stirling I, Richardson ES. Fasting physiology of polar bears in relation to environmental change and breeding behavior in the Beaufort Sea. Polar Biol 2009;32:383-391.

Christensen JR, Macduffee M, Yunker MB, Ross PS. Hibernation-associated changes in persistent organic pollutant (POP) levels and patterns in British Columbia grizzly bears (Ursus arctos horribilis). Environ Sci Technol 2007;41:1834-1840. 
Conesa A, Gotz S, Garcia-Gomez JM, Terol J, Talon M, Robles M. Blast2GO: a universal tool for annotation, visualization and analysis in functional genomics research. Bioinformatics $2005 ; 21: 3674-3676$.

Derocher AE, Aars J, Amstrup SC, Cutting A, Lunn NJ, Molnár PK, et al. Rapid ecosystem changes and polar bear conservation. Conserv Lett 2013;6:368-375.

Dietz R, Gustavson K, Sonne C, Desforges JP, Rigét FF, Pavlova V, et al. Physiologically-based pharmacokinetic modelling of immune, reproductive and carcinogenic effects from contaminant exposure in polar bears (Ursus maritimus) across the Arctic. Environ Res 2015;140:45-55.

Durner GM, Douglas DC, Nielson RM, Amstrup SC, McDonald TL, Stirling I, et al. Predicting 21st-century polar bear habitat distribution from global climate models. Ecol Monogr 2009;79:25-58.

Edwards CJ, Suchard MA, Lemey P, Welch JJ, Barnes I, Fulton TL, et al. Ancient hybridization and an Irish origin for the modern polar bear matriline. Curr Biol 2011;21:1251-1258.

375 Falcon S, Gentleman R. Using GOstats to test gene lists for GO term association. Bioinformatics $376 \quad 2007 ; 23: 257-258$.

377 Gormezano LJ, Rockwell RF. Dietary composition and spatial patterns of polar bear foraging on $378 \quad$ land in western Hudson Bay. BMC Ecol 2013a;13:51.

379 Gormezano J, Rockwell RF. What to eat now? Shifts in polar bear diet during the ice-free season 380 in western Hudson Bay. Ecol Evol 2013b;3:3509-3523.

381 Götz S, Garcia-Gomez JM, Terol J, et al. High-throughput functional annotation and data mining 382 with the Blast2GO suite. Nucleic Acids Research 2008;36:3420-3435. 
Grabherr MG, Haas BJ, Yassour M, Levin JZ, Thompson DA, Amit I, et al. Full-length transcriptome assembly from RNA-seq data without a reference genome. Natl Biotech 2011;29:644-652.

Graham AL, Shuker DM, Pollitt LC, Auld SKJR, Wilson AJ, Little TJ. Fitness consequences of immune responses: strengthening the empirical framework for ecoimmunology. Funct Ecol 2010;25:1-13.

389 Helgason LB, Wolkers J, Fuglei E, Ahlstrom O, Muir D, Jorgensen EH. Seasonal emaciation causes tissue redistribution and an increased potential for toxicity of lipophilic pollutants in farmed arctic fox (Vulpes lagopus). Environ Toxicol Chem 2013;32:1784-1792.

Iles DT, Peterson SL, Gormezano LJ, Koons DN, Rockwell RF. Terrestrial predation by polar bears:not just a wild goose chase. Polar Biol 2013;36:1373-1379.

Jenssen BM, Villanger GD, Gabrielsen KM, Bytingsvik J, Bechshøft TØ, Ciesielski TM, et al. Anthropogenic flank attack on polar bears: Interacting consequences of climate warming and pollutant exposure. Front Ecol Evol 2015;3:1-7.

Kim D, Pertea G, Trapnell C, Pimentel H, Kelley R, Salzberg SL. TopHat2: accurate alignment of transcriptomes in the presence of insertions, deletions and gene fusions. Genome Biology 2013; 14:R36.

Letcher RJ, Bustnes JO, Dietz R, Jenssen BM, Jørgensen EH, Sonne C, et al. Exposure and effects assessment of persistent organohalogen contaminants in arctic wildlife and fish. Sci Total Environ 2010;408:2995-3043.

Li H, Durbin R. Fast and accurate long-read alignment with Burrows-Wheeler transform. Bioinformatics 2010;26:589-595. 
Lie E, Larsen HJS, Larsen S, Johansen GM, Derocher AE, Lunn NJ, et al. Does high organochlorine (OC) exposure impair the resistance to infection in polar bears (Ursus maritimus)? Part 1: effect of OCs on the humoral immunity. J Toxicol Environl Health 2004;67(Pt A):555-582.

Lie E, Larsen HJ, Larsen S, Johansen GM, Derocher AE, Lunn NJ, et al. Does high organochlorine (OC) exposure impair the resistance to infection in polar bears (Ursus maritimus)? Part II: Possible effect of OCs on mitogen-and antigen-induced lymphocyte proliferation. J Toxicol Environ Health 2005;68(Pt A):457-484.

Lynch M, Kirkwood R, Mitchell A, Duignan P, Arnould JPY. Prevalence and significance of an alopecia syndrome in Australian fur seals (Arctocephalus pusillus doriferus). J Mamm 2011;92:342-351.

Macdonald RW,Harner T, Fyfe J.Recent climate change in the Arctic and its impact on contaminant pathways and interpretation of temporal trend data. Sci Total Environ $2005 ; 342: 5-86$.

419 Martin LB, Hopkins WA, Mydlarz LD, Rohr JR. The effects of anthropogenic globalchanges on 420 immune functions and disease resistance. Annu NY Acad Sci 2010;1195:129-148.

421 McKinney MA, Peacock E, Letcher RJ. Sea ice-associated diet change increases the levels of $422 \quad$ chlorinated and brominated contaminants in polar bears. Environ Sci Tech 2009; $423 \quad 43: 4334-4336$.

424 McKinney MA, Iverson SJ, Fisk AT, Sonne C, Riget F, Letcher RJ, et al. Global change effects on the long-term feeding ecology and contaminant exposures of East Greenland polar bears. Glob Change Biol 2013;19:2360-2372. 
McLoughlin K, Turteltaub K, Bankaitis-Davis D, Gerren R, Siconolfi L, Storm K, et al. Limited dynamic range of immune response gene expression observed in healthy blood donors using RT-PCR. Mol Med 2006;12:185-195.

Miles AK, Bowen L, Ballachey B, Bodkin JL, Murray M, Estes JL, et al. Variations of transcript profiles between sea otters (Enhydra lutris) from Prince William Sound, Alaska, and clinically normal reference otters. Mar Ecol Prog Ser 2012;451:201-212.

Molnar PK, Derocher AI, Klanjscek T, Lewis MA. Predicting climate change impacts on polar bear litter size. Nat Commun 2011;2:186.

National Oceanic and Atmospheric Administration (NOAA). 2011 Arctic Seal Disease Outbreak Update on Investigation and Findings. Alaska, U.S. Department of Commerce. 2011. Available from: http://alaskafisheries.noaa.gov/protectedresources/seals/ice/diseased/factsheet112211.

Parra G, Bradnam K, Korf I. CEGMA: a pipeline to accurately annotate core genes in eukaryotic genomes. Bioinformatics 2007; 23: 1061-1067.

Pedersen AB, Babayan SA. Wild immunology. Mol Ecol 2011;20:872-880.

Polischuk SC, Norstrom RJ, Ramsay MA. Body burdens and tissue concentrations of organochlorines in polar bears (Ursus maritimus) vary during seasonal fasts. Environ Pollut 2002;118:29-39.

445 Ramsay MA, Stirling I. Reproductive biology and ecology of female polar bears (Ursus 446 maritimus). J Zool 1988;214:601-634.

447 Ramsay MA, Hobson KA. Polar bears make little use of terrestrial foodwebs-evidence from 448 stable-carbon isotope analysis. Oecologia 1991;86:598-600. doi:10.1007/BF00318328. 
Regehr EV, Lunn NJ, Amstrup SC, Stirling I. Effects of earlier sea ice breakup on survival and population size of polar bears in Western Hudson Bay. J Wildl Manag 2007;71:26732683.

Regehr EV, Hunter CM, Caswell H, Amstrup SC, Stirling I. Survival and breeding of polar bears in the southern Beaufort Sea in relation to sea ice. J Anim Ecol 2010;79:117-127.

Robinson MD, McCarthy DJ, Smyth GK. edgeR: a Bioconductor package for differential expression analysis of digital gene expression data. Bioinformatics 2010;26:139-140.

Rode KD, Amstrup SC, Regehr EV. Reduced body size and cub recruitment in polar bears associated with sea ice decline. Ecol Appl 2010;20:768-782.

Rode KD, Robbins CT, Nelson L, Amstrup SC. Can polar bears use terrestrial foods to offset lost ice-based hunting opportunities? Front Ecol Enviro 2015;13:138-145.

Rogers M, Peacock E, Simac K, O’Dell M, Welker J. Diet of female polar bears in the southern Beaufort Sea of Alaska: evidence for an emerging alternative foraging strategy in response to environmental change. Pol Biol online March 2015.

Saucillo DC, Gerriets VA, Sheng J, Rathmell JC, Maclver NJ. Leptin metabolically licenses T cells for activation to link nutrition and immunity. J Immunol 2014;192:136-144.

Schliebe SC, Rode KD, Gleason JS, Wilder J, Proffitt K, Evans TJ, et al. Effects of sea ice extent and food availability on spatial and temporal distribution of polar bears during the fall open-water period in the southern Beaufort Sea. Polar Biol 2008;31:999-1010.

Sonne C. Health effects from long-range transported contaminants in Arctic top predators: an integrated review based on studies of polar bears and relevant model species. Environ Int 2010;36:461-491. 
471 Stirling I, Thiemann GW, Richardson E. Quantitative support for a subjective fatness index for immobilized polar bears. J Wildl Manag 2008;72:568-574.

473 Stirling I, Derocher AE. Effects of climate warming on polar bears: a review of the evidence.

$474 \quad$ Global Change Biol 2012;18:2694-2706.

475 Stroeve J, Serreze M, Holland M, Kay J, Malanik J, Barrett A. The Arctic's rapidly shrinking sea 476 ice cover: A research synthesis. Clim Chang 2012;110:1005-1027.

477 Stroeve J, Markus T, Boisvert L, Miller J, Barrett A. Changes in the Arctic melt season and 478 implications for sea ice loss. Geophys Res Lett 2014;41:1216-1225.

479 Supek F, Bosnjak M, Skunca N, Smuc T. REVIGO summarizes and visualizes long lists of gene 480 ontology terms. PLoS ONE 2011; 6:e21800.

481 Thiemann GW,Iverson SJ, Stirling I. Polar bear diets and arctic marine food webs: insights from 482 fatty acid analysis. Ecol Monogr 2008;78:591-613.

483 Vos JG, Dybing E, Greim HA, Ladefoged O, Lambre C, Tarazona JV, et al. Health effects of 484 endocrine-disrupting chemicals on wildlife, with special reference to the European $485 \quad$ situation. Crit Rev Toxicol 2000;30:71-133. 


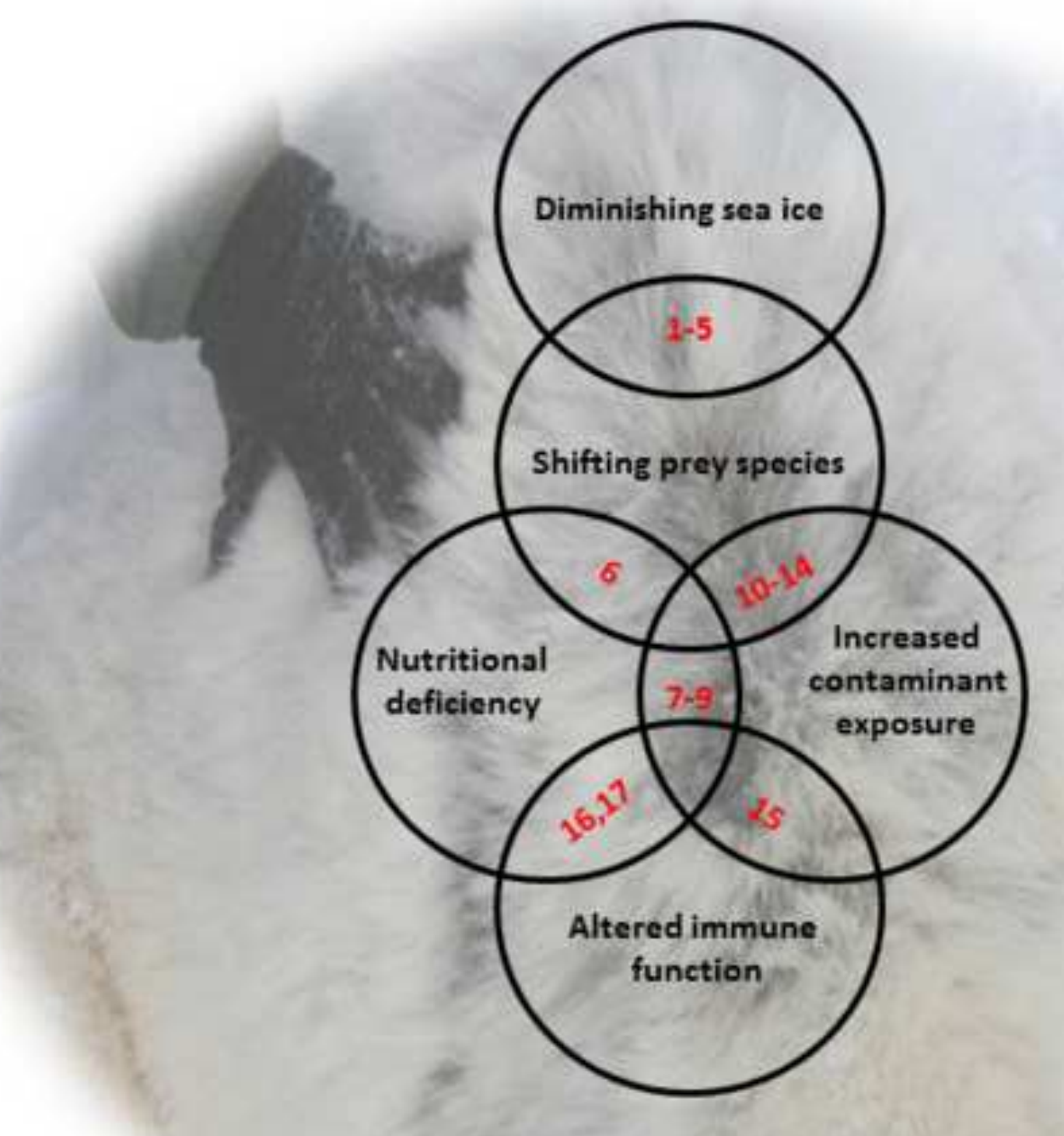

